\title{
Scientific development and a new green deal
}

\author{
Xiaoxi Li
}

\author{
Correspondence: \\ Ixx62205058@163.com \\ School of Economics and Resource \\ Management, Beijing Normal \\ University, Beijing 100875, China
}

\begin{abstract}
After 30 years of reform and opening, China has become the world's second largest economy. However, the fast growth has come at the high cost of environmental degradation and resource consumption. The existing resource reserves and environment will not able to sustain the rapid economic development of the future, which demands China to transform its model for development. China should keep pace with the trend of world civilization and grasp the opportunity for green development.

Keywords: Resources and environment; Ecological civilization; Green development
\end{abstract}

The past three decades are characterized by reform-driven development. With economic and social development today, it is difficult to maintain harmony between humans and nature and among people. We must begin to think about the development model in new ways.

\section{First, it is undeniable that China's economic and social development is driven by extensive resource investment}

China's rapid economic growth comes at the high price of resource exhaustion and environmental degradation. Secondary industry is still the main driver of gross domestic product (GDP) growth in China. This high-polluting, high-energy-consuming and resource-dependent industry imposes great pressure on natural resource demand, and environmental degradation is acute. Besides, resource and labor-intensive products are the major driving force for the rapid growth of China's exports, which aggravates resource scarcity and environmental degradation. Since poverty reduction and economic development are still the top concerns of developing countries, their environment policies and regulations are not as stringent as those of developed countries. As a result, a significant amount of industry, especially resource-intensive industry, is transferred to China from other countries (Xue 2009).

Total energy consumption and energy consumption per unit of GDP are high in China. In the six decades since 1949, China's GDP has increased over ten times, while mining and resource consumption has increased over 40 times and is growing year by year. China consumes $11 \%$ of world energy and contributes only $3 \%$ to total output value. China's energy efficiency is $33 \%, 10 \%$ lower than that of developed countries. Its energy consumption per unit of output value is twice as much as the world average. The per-unit energy consumption of eight industries (chemical, electricity, steel, nonferrous metals, construction material, petrochemicals, textiles, and light industry) in China is $40 \%$ higher than that in the advanced countries. The average efficiency of

(c) $2014 \mathrm{Li}$; licensee Springer. This is an Open Access article distributed under the terms of the Creative Commons Attribution License (http://creativecommons.org/licenses/by/2.0), which permits unrestricted use, distribution, and reproduction in any medium, provided the original work is properly cited. 
boiler operation of the coal power industry is $15 \%$ to $20 \%$ lower than the world advanced level. Vehicle fuel consumption per kilometer is $25 \%$ and $20 \%$ higher than that in Europe and Japan, respectively. In addition, the energy consumption of air conditioners and building heating is higher than developed countries. In particular, per-unit energy consumption for heating buildings in China is two to three times that of developed countries with similar climates (Guo and Zheng 2009).

Ecological degradation coexists with a difficulty in treating pollution. In the past 30 years, the economic loss caused by the environment pollution is equal to $10 \%$ of China's aggregate GDP (Han 2006). First, pollution has squeezed the environmental space for social development. Land desertification has accelerated in some areas, causing direct economic losses of up to 50 billion RMB and threatening 400 million people in China. In addition, half of China's impoverished population lives in the affected area. Land desertification has become one of the serious dangers looming over China ${ }^{\mathrm{a}}$. A fifth of Chinese cities are heavily polluted. The air quality in more than a third of key cities fails to reach National Level 2, and vehicle emissions contribute a significant portion of this. Coal combustion has replaced vehicle emissions as the major pollution source in some Chinese cities. In a report published in the mid-1990s, the World Bank pointed out that the losses caused by the air and water pollution in China were equal to $8 \%$ of its GDP in 1995 . Some researchers warn that the bite environmental degradation is now taking out of GDP is over $17 \%$.

\section{Second, overinvestment is a result of an imperfect system}

Price is an important tool for resource allocation and environmental protection in a market economy. Dysfunctional resource allocation, the result of price distortions, plays an important part in restraining sustainable development. For some time, resources and the environment have been seen as low-value public goods that can be used at will. Resources are underpriced, which fails to reflect the relationship between market demand and supply or the scarcity of resources. Prices cannot act as a restriction or an incentive to investors, businesses, and consumers. The government manipulates the prices of important resources; for example, land, water, and oil are manipulated for the sake of maintaining low prices or curbing inflation. Resource scarcity and the market reality are severely distorted by this low-price policy, which results in waste and overconsumption of the important resources.

Effective management is important for energy conservation and environmental protection. The inadequate management system in China constrains the role of resources and the environment in the sustainable development. Although China has promulgated the Energy Conservation Law, Mineral Resources Law, Water Law, Cleaner Production Promotion Law, and the Renewable Resource Law, it still has a weak legal system for energy conservation and comprehensive resource utilization, especially in the recycling of renewable resources. Some legal clauses fail to keep pace with the development of the socialist market economy. Some laws are too general to be enforced. The legal duties and obligations of economic entities for energy conservation and environmental protection are not clearly defined. The preciousness of law is undermined by insufficient law enforcement and supervision. It is difficult for authorities to punish the wasting of resources and damage to the environment, which aggravates the resource waste in China. 
The Chinese government has promulgated laws and regulations on environmental protection since the policy of reform and opening. However, there are still many defects, for instance, ineffective and unitary laws, ecological compensation, improper standards, and absence of effective supervision, etc. Sewage and garbage are treated as waste instead of resources for recycling, so that the operations of environment infrastructure facilities are not industrialized. The construction of environment infrastructure is regarded as a charity activity in China. From initial investment to final operation, the entire process is exclusively managed by the government in many Chinese cities. The defects in the system and mechanisms greatly constrain the development of the urban environmental undertaking (Leng and Leng 2007).

Water resource efficiency is low in China. Agriculture is the largest water consumer and contributes $62 \%$ to total water consumption in China. The coefficient of irrigative water utilization is about 0.45 in northwest China and 0.6 in eastern coastal regions due to extensive irrigation and poor canal seepage control, while it is around 0.85 in the developed countries. Industrial water consumption is rather high. Water consumption of per 10,000 RMB of GDP is as high as $399 \mathrm{~m}^{3}$ in China, while it is only $55 \mathrm{~m}^{3}$ in the developed countries. The water reuse rate is lower than 0.4 in the majority of Chinese regions and 0.7 in the developed countries. Urban household water use is rarely allocated by the market, and residents usually lack a sense of water conservation. The pipeline leakage rate in China is $21 \%$, while it is only $5 \%$ to $10 \%$ in developed countries.

The unscientific crop planting structure and farming system break the balance between the land ecosystem and environmental factors. It even leads to water and soil loss and desertification in some areas; as a result of which, regional resource reserves are in decline. A great deal of resources are not utilized efficiently and are treated as waste, which destabilizes the environmental system and constrains sustainable social and economic development.

\section{Third, only through deeper reform can China realize the transformation of its development model and sustainable development featuring balanced output}

Deng Xiaoping once said, 'Reform is the impetus for development; development is the goal of reform; and stabilization is the prerequisite for reform and development'. System reform does not mean taking reform on its own merit. It means promoting economic and social development by sorting out production relationships and building and improving. Given the fact that development is the ultimate goal, reform will be judged by whether it will promote economic and social development. Only the appropriate development model can promote worthwhile reform. Since reform and opening, it has taken China just over 30 years to achieve what took developed countries 100 years to accomplish in industrialization and urbanization. Against that background, on one hand, development difficulties and social conflicts, gradually resolved over 100 years in Western developed countries, have emerged in a 'compressed timespan' in China. On the other hand, China lacks experience in the management of industrialization, urbanization, and marketization. This dilemma brings with it a number of social problems. It is urgent for China to transform its development model and select the one that fits its national conditions and the development of the times. 
Because of systemic and mechanism problems, like systemic barriers and an imperfect economic and legal environment, it is difficult for China to transform the coarse development model. A breakthrough will not be achieved in the model transformation without future reforms that would optimize resource allocation and improve utilization efficiency. The market for production factors, like capital, land, and natural resources, should be put in place and improved in China. The compensation mechanism for resource exploitation and ecosystem recovery should be improved to boost resource conservation and intensive development. The reform of the administration system must take the acceleration of the transformation of government functions as the main thread. In order to create a sound systemic environment for transforming the economic development model, the Chinese government should enhance its function of social management and public service by shifting from an allround and regulatory-type government to a limited and service-type government ruled by laws.

\section{Fourth, the transformation of the economic development model, to a certain extent, means developing the green economy with systemic guarantees}

The green economy is one that features protecting the living environment and resources for the sake of human health. It is preceded by the all-round development of humanity, ecosystem capacity, and resource carrying capacity. It is the pursuit of the sustainable utilization of natural resources and economic development as well as continuous improvement of the ecosystem and the quality of life. In the short run, development of the green economy will create job opportunities and revitalize the economy. Meanwhile, it will be conducive to economic restructuring and striving for a balance between resource and environment protection and economic development. In the long run, it will facilitate continuous and intensive economic growth, and then truly coordinated and sustainable development will be achieved.

Transforming economic development mode and developing green economy require systemic guarantees. In China, systemic guarantee means implementing a Green New Deal. This borrows the concept from the United Nations (UN) and is for its own needs. UNEP initiated the Global Green New Deal in October 2008. It states that the twentyfirst century represents a historic moment for focusing investment on environmental protection, which will ensure economic prosperity and create job opportunities. At the United Nations Climate Change Conference (December 11, 2008) and World Environment Day event (June 2009), Ban Ki-moon, the UN Secretary-General, stressed the importance of the Green New Deal several times. He stated that the world needs a Green New Deal that focuses on investment in renewable resources, building environmentally friendly infrastructure, and increasing energy efficiency. He stated that today's crisis could be transformed into tomorrow's sustainable growth if part of the economic stimulus packages was invested in the green economy.

In April 2009, UNDP published a report titled A Global Green New Deal and expounded on the basic content of the program. The Green New Deal announced by President Obama covered many aspects like energy conservation, efficiency increases, new energy exploitation, and tackling climate change, among which was new energy exploitation as the core of the Deal. With his New Deal, President Obama was even called 
as the First Green American President. In the UK, the Green New Deal pushed the economic development towards a low-carbon orientation.

\section{Fifth, the concept of scientific development and the New Green Deal are in line with China's national conditions and conducive to its development}

First, the idea of a New Green Deal is widely accepted around the world, making it easy for China to reach a consensus with international society and be recognized and understood by developed countries.

Second, this idea makes future reforms more feasible. If reform is only based on the concept of the socialist market economy and restructuring the interest pattern, it will be very difficult to reach consensus among the parties concerned. The Green New Deal presents us with the opportunity to base reform on a less disputed target. It makes reform more workable and less obstructed in China. The transformation of the economic development model will involve many matters relating to the economic system. These matters will turn out to be the key points in the reform of economic system. For instance, how can China conserve energy and reduce emissions while maintaining the development of the economy and continuing to increase the well-being of the people? How can we have economic growth driven by green industry? What should we do to enhance international cooperation on green industry? These easily addressed and concrete matters will prevent system reform from being reduced to empty talk.

Third, the New Green Deal is beneficial for a smooth relationship between the government and the market. The function and role of the government and the market will be well defined in the New Green Deal. The Deal, the essence of which is innovation, clearly states the sound way of environment protection, resource consumption, and green development. The conventional concept of sustainable development is for the long term and cross-period. The proposed idea of the New Green Deal is for a limited period, namely, its implementation could be within the control of government leaders during their terms. It is a very realistic idea and easily designed and operated.

Fourth, the New Green Deal is consistent with the essence of China's 12th Five Year Plan, which attaches great importance to green development policy. Future work is conducive to starting from this foundation (Wen 2012).

Fifth, the New Green Deal is conducive to smoothing fiscal revenue allocation between central and local governments and among local governments. Under the Deal, the boundary between central revenue and local revenue could be distinctly defined by an ecological compensation system; with the help of which, there would be effective fiscal revenue allocation between central and local governments. The New Green Deal will streamline the urban-rural relationship. There is a complete set of key performance indicators for industrialization, urbanization, and agriculture modernization in the New Green Deal. Since the New Green Deal is based on the theory of the welfare economy, it emphasizes the integration of the economy and social theory. It pays attention to both economic development and people's well-being, like employment and living standards. Therefore, it will strive to strike a balance between economic and social development. Moreover, the Deal is beneficial for streamlining the relationship between the government and civil organization. Nevertheless, the Green New Deal is only a facilitator of reform and will not be able to complete all the tasks of reform. 
Sixth, if you want to leverage the power of nature, you must accommodate yourself to nature. In other words, the mindset of human beings triumphing over nature should be changed to an attitude of seeking harmony between human beings and nature. This is the most important lesson learned from the economic development of China over the past three decades.

The God of nature, whether God in the Western sense or Buddha or the Heavenly Lord in the Eastern sense, has created a green world for us. If human beings did not emerge, the earth would still be covered by vast, unexploited land and oceans. Today's desert was once dominated by water and plant life. The expansion of the green world is well regulated by the natural powers, like earthquake, thunder, and lighting.

Nature has protected human beings since their appearance on the earth, giving us the basic conditions for life. In ancient China, philosophers proposed the thought of the integration of human beings and heaven and following nature. It stresses the harmony between nature and human beings as well as admiration of the laws of nature. Since industrialization, human beings have acquired a strong power to leverage nature and modernize the world. In turn, nature has also taken revenge on human beings for abusing this power. Humans have not been aware of the mistake we have made until a few years ago. Now, we start to show our kindness towards nature and would like to create harmony between two sides with the New Green Deal.

Furthermore, the harmonious relationship among people plays an important part in maintaining the green ecosystem. The unharmonious relationship among people, especially war, brings great damage to nature. War causes massive deforestation. Improper thought and policy leads to endless exploitation and unscientific planning, which change the face of nature. For a green world, we need peace and a New Deal. For a green world, we request the government to better play its role. This triggers the discussion on how to secure harmony among people and ethnic groups to eliminate revenge and war in the country. In addition, every country is obliged to respect international laws and treaties to maintain the world peace. The rogue state that treats the peaceseeking state as weak should be punished by both tough and soft tactics.

\section{Seventh, build an ecological civilization and strive for beautiful China}

The idea of building a beautiful China is stated in the Report of the Communist Party of China (CPC) delivered at its 18th National Congress. It is the first time for China to officially announce this idea. The timely announcement is demanded by the future implementation of the outlook on scientific development and the sustainable development of the Chinese nation. It is inevitable for economic and social development in the new stage. Confronted by the growing scarcity of resources, environmental pollution, and ecological degradation, we must have the concept of respecting, following, and protecting nature. The ecological progress should be put on top of the agenda because it is vital for the nation's future and people's well-being. Striving for a beautiful China clearly defines the target for ecological progress.

Beautiful China highlights the importance of ecological progress, which leads to high expectations on environmental protection and recovery. It also raises tough requirements on urbanization and industrialization. It has a strong appeal for sustainable development in urban areas. China is still in the process of industrialization and 
urbanization, which bring daunting tasks for environmental remediation. We are far from truly beautiful. In many areas, it is even difficult to secure the safety of drinking water, maintain the green landscape, prevent the ground from collapsing, and keep the air breathable. However, this cannot be used as an excuse for neglecting the vision of a beautiful China. Without the target of being beautiful, the work standard will be degraded automatically. Without the target of being beautiful, there is no vision for urban planning. Consequently, ecological progress will stand still, which adds burden to the future ecology. The idea of a beautiful China touches the dreams of the public. It is more appealing to the public, easy to inspire all walks of society, and to be observed by the people.

In order to build a beautiful China, we have to put ecological progress on top of the agenda. It should be fully integrated into economic, political, cultural, and social development. We should strive for green, circular, and low-carbon development. We should preserve our geographical space and improve our industrial structure, way of production, and way of life in the interest of conserving resources and protecting the environment. In short, we will highlight ecology and strive for green development in five dimensions.

A beautiful China cannot be built in 1 day. We should be well prepared for a prolonged battle. Its realization depends on a system of organization that is established through concerted efforts. We must be keenly aware that a beautiful China demands both the superficial and the substantial. The superficial is represented by the beautiful landscape, while the substantial is illustrated by the combination of soft power and hard power. Understanding the essence of a beautiful China requires us to strive to retain the beautiful rather than settle for transient beauty. Efforts should go to protecting the ecosystem and promoting five-dimensional ecological progress. This will bring true and reliable beauty to the people.

In conclusion, development in China has been driven by reform in the past three decades since the Third Plenary Session of the 11th Central Committee of the CPC. To transform the model of economic development, we must choose a high-quality and effective development direction to promote reform. There is no doubt that scientific development and the New Green Deal would facilitate system innovation. But the task of comprehensive reform to the political and economic systems must be planned as soon as possible and launched when the time is ripe.

\section{Endnote}

${ }^{a}$ See 'The sandification and desertification area is as high as 2.6362 million square $\mathrm{km}$ in China, http://chinanews.com, September 24, 2009.

Competing interests

The author declares that he has no competing interest.

\section{Author's information}

Li XX is the Vice Director of the Academic Board and Honorary Dean of School of Economics and Resource Management of Beijing Normal University, Convener of the Economic Section of the Social Science Committee of Ministry of Education of China, Professor and PhD Supervisor of the Graduate School of the Chinese Academy of Social Sciences, Visiting Professor for Peking University and other key universities in China, Director of the Institute of Capital Science Strategy Development, Member of the China Council for International Cooperation on the Environment and Development, and Director of the Research Center of Asia-Pacific Green Development. He is also Vice Director of China Market Study Association and member of other 20 councils. He worked in the London School of Economics and Political Science (LSE) as a visiting scholar in 1988. He worked in the Research Office of the State Council of China from 1993 to 2001 and once took the office of Director of Commission of Macroeconomic Study. In 
2001, he was transferred to Beijing Normal University. The Report on Market Economy Development in China was formulated under his leadership. In addition, the Report on Green Development Index in China was formulated under his leadership for 3 years. He publicized around 300 articles and 40 books in past three decades, some of which were awarded with First Class of China Book Prize, China Soft Science Prize, Sun Yefang Economy Prize, and Wu Yuzhang Economy Prize.

Received: 24 November 2012 Accepted: 8 November 2013

Published: 2 January 2014

\section{References}

Guo W, Zheng Y (2009) Low-carbon economy, opportunities and challenges facing China in next 40 years (低碳经济:

未来四十年我国面临的机遇与挑战). China Opening Herald (开放导报), No.4, pp 5-9

Han B (2006) Six bottlenecks constraining economic growth (六大瓶颈制约经济增长). People's Tribune (人民论坛), No.24, pp 16-17

Leng S, Leng C (2007) Review of resource constrain and sustainable development (资源环境约束与可持续发展问题 研究). Price Monthly (价格月刊), No.11, pp 3-9

Wen J (2012) Premier Wen Jiabao's report on government work. http://www.eeo.com.cn/2012/0305/221970_6.shtml

Xue H (2009) The mechanism for interaction between resource \& environment problem and social \& economic problems in China (中国资源环境问题与社会经济问题的作用机理). China Environment News (中国环境报)

doi:10.1186/2196-5633-2-2

Cite this article as: Li: Scientific development and a new green deal. China Finance and Economic Review 2014 2:2.

\section{Submit your manuscript to a SpringerOpen ${ }^{\circ}$} journal and benefit from:

- Convenient online submission

- Rigorous peer review

- Immediate publication on acceptance

- Open access: articles freely available online

- High visibility within the field

- Retaining the copyright to your article

Submit your next manuscript at $\gg$ springeropen.com 